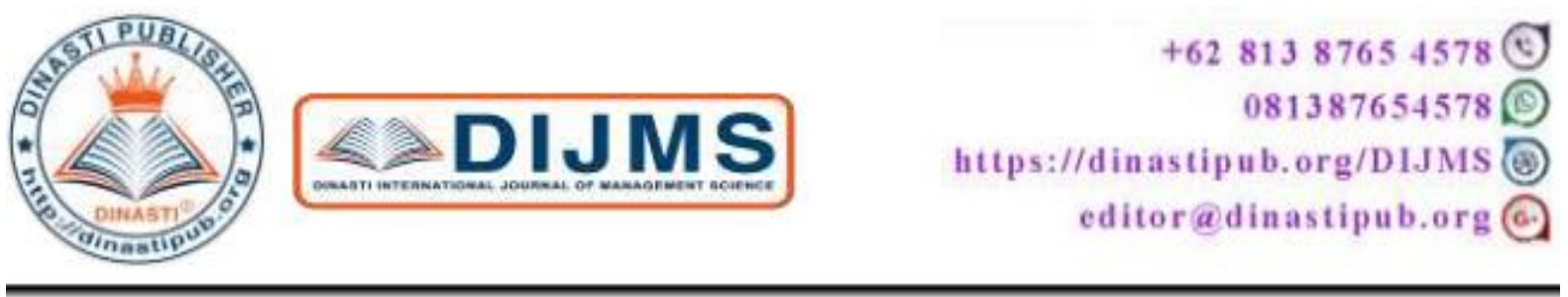

\title{
THE INFLUENCE OF PROFIT AND CASH FLOW TO PREDICT FINANCIAL DISTRESS
}

\section{Tongam Sinambela ${ }^{1}$, Agus Irawati Marpaung ${ }^{2}$}

${ }^{1)}$ Faculty of Eocnomic, Universitas Mpu Tantular, Indonesia

${ }^{2)}$ Faculty of Eocnomic, Universitas Mpu Tantular, Indonesia

\begin{tabular}{|c|c|}
\hline $\begin{array}{l}\text { Corresponding author: first author } \\
\text { E-mail: } \\
\text { tongam_ssm@yahoo.co.id } \\
\underline{\text { marpaungira@gmail.com }}\end{array}$ & $\begin{array}{l}\text { Abstract: This study aims to examine and analyze } \\
\text { how profit and cash flow individually or collectively } \\
\text { could influence the prediction of financial distress. } \\
\text { This study uses quantitative data methods using the } \\
\text { Altman Z-Score analysis method. Data analysis is } \\
\text { performed through Eviews } 8 \text { software application. The } \\
\text { population in this study are all manufacturing } \\
\text { companies listed on the Indonesia Stock Exchange } \\
\text { (IDX) in the period from } 2015-2018 \text {. The samples used } \\
\text { are all manufacturing companies with subsector of } \\
\text { plastic and packaging. Data analysis in this study uses } \\
\text { econometric model with a simultaneous equation } \\
\text { system and data panel estimation method. The results } \\
\text { of the study prove that profit does not have a } \\
\text { significant effect on financial distress. This is } \\
\text { supported by t-test analysis which result in a smaller t- } \\
\text { count compared to t-table, with the number - } 1.76 \\
<2.05 \text {, therefore, H1 is rejected. On the other hand, } \\
\text { cash flow has a significant effect on financial distress, } \\
\text { supported by the result of t-test analysis which shows } \\
\text { that the t-count is bigger than t-table, with the number } \\
2.67>2.05 \text {. Therefore, H } 2 \text { is accepted. Whereas, both } \\
\text { profit and cash flow have a significant influence on } \\
\text { financial distress, which the results of the analysis of } \\
\text { the F test is f-count is higher that f-table, with the } \\
\text { number } 17.45>170.77 \text {. As a result, H3 is accepted. } \\
\text { Keywords: Profit, Cash Flow, Financial Distress. }\end{array}$ \\
\hline
\end{tabular}




\section{INTRODUCTION}

Every company aims to make a profit so that it can survive or develop in the long period and does not experience liquidation. One of the uses of profit statement (Harahap, 2011: 57) is to determine the company's ability to distribute dividends to investors. In fact, this assumption does not always occur as expected. Often companies that have been operating for a certain period of time are forced to disperse or be liquidated due to financial difficulties that lead to bankruptcy.

Some of the indication of bankruptcy needs to be assessed to anticipate bankruptcy in the future (Loman, Raissa Karina Male, Mariana Ing, 2015). The way to do this is to analyze the company's financial ratio through certain models such as the Z-Score model and other models.

In addition, cash flow is a financial statement providing relevant information about revenues and expenditures within a certain time period. Every company in operating its business will experience cash inflows and cash outflows. If the cash inflows are greater than the cash outflows, this will show positive cash flows, on the contrary if the cash inflows are less than the cash outflows, there will be negative cash flows. The information of Cash flow is needed by investors and creditors to determine the company's ability to repay debts. If the cash flow of a company is considerable, the creditor will be confident that the company can return the loan, get the confidence of returning the loan. Conversely, the creditors do not get confidence in the company's ability to pay debts if the cash flow is insignificant.

There have been many studies about financial distress completed, such as research by Nailufar, F., \& Badaruddin, S. (2018), Fanni Djongkang (2014), Frans Julius (2014), Dean Subhan Saleh (2016) which explained that the prediction of both profit and cash flow can reveal the occurrence of financial distress in the company. In contrast, studies by Santoso, Fala, \& Khoirin's (2017), Setiawan, D., Oemar, A., \& Pranaditya, A (2015) indicated that corporate governance had a negative effect on financial distress, whereas profit and cash flow failed to show any effect on financial distress.

This study is to test the consistency of the study between Nailufar, F. \& Badaruddin, S (2018) and the research conducted by Santoso, Fala, \& Khoirin (2017). In addition, this study uses a different sample from previous studies. While the objects of study by Nailufar, F \& Badaruddin, S. (2018) was all manufacturing companies, and study by Santoso, Fala, \& Khoirin research, 2017 took the objects in non-bank manufacturing companies, this research's object is the manufacturing companies with subsector of plastic and packaging within $2015-2018$.

This study addresses the problem of whether profits and cash flow independently can be used to predict the occurrence of financial distress and whether both profit and cash flow collectively can be used to predict financial distress conditions.

\section{LITERATURE REVIEW}

Financial distress can be defined as a financial condition of a company experiencing severe liquidity problems which the company is unable to run its operations properly. Altman (1968) defined financial distress by using numbers in financial statements and then 
representing them in Z-Score which can be a reference to determine whether a company has the potential to experience bankrupt or not.

Altman z-score model is an indicator to measure the potential bankruptcy of a company. A number of studies have been conducted to determine the effectiveness of financial ratio analysis in predicting the failure or bankruptcy of a company. One of the studies on this prediction is multiple discriminant analysis (MDA), which is commonly called the Altman model Z-score method. The rationale for Altman to use discriminant analysis started from the limitations of ratio analysis, where the methodology was basically a deviation where each ratio was tested separately.

The financial variables or ratios used in the discriminant analysis of Altman model are (Katarina Intan Afni Patunrui, 2017):

\section{Net Working Capital to Total Assets (WCTA)}

This ratio shows the company's ability to generate net working capital from the total assets it has. This ratio is calculated by dividing net working capital by total assets. Net working capital is obtained by subtracting the current liabilities by the current assets. Negative net working capital is likely to face problems covering its short-term obligations due to the unavailability of sufficient current assets to cover these obligations. Conversely, company with positive working capital net will rarely face difficulties in paying of their obligations. With the ratio formula as follows:

$$
\mathrm{X} 1: \text { WCTA }=\frac{\text { Working Capital }}{\text { Total Assets }}
$$

\section{Retained Earnings to Total Assets (RETA)}

This ratio shows the company's ability to generate retained earnings from total company assets. Retained earnings are profits which are not distributed to shareholders. On other words, retained earnings shows how much the income of a company is not paid in the form of dividends to the shareholders. Therefore, the retained earnings reported in the balance sheet are not real cash and not available for dividend payments or otherwise. With the ratio formula as follows:

$$
\mathrm{X} 2: \text { RETA }=\frac{\text { Retained Earnings }}{\text { Total Assets }}
$$

\section{Earnings Before Interest and Tax to Total Assets (EBITTA)}

This ratio shows the company's ability to generate profits from total company assets before payment of interest and taxes. With the ratio formula as follows:

Earning Before Interest and Taxes

$$
\mathrm{X} 3: \mathrm{EBITTA}=\overline{\text { Total Assets }}
$$

\section{Market Value of Equity to Book Value of Debt (MVEBVL)}


This ratio shows the ability of a company to fulfill its obligation from the market value of its own capital (common shares). The market value of equity itself is obtained by multiplying the number of shares of common stock outstanding by the market price per common share. The book value of debt is obtained by adding up current liabilities to longterm liabilities. With the ratio formula as follows:

$$
\mathrm{X} 4: \mathrm{MVEBVL}=\frac{\text { Market Value of Equity }}{\text { Book Value of Total Debt }}
$$

\section{Sales to Total Assets}

This ratio shows whether the company produces adequate business volumes compared to the investment in total assets. This ratio reflects the efficiency of management in using the company total assets to generate sales and obtain profits. With the ratio formula as follows:

$$
\mathrm{X} 5: \mathrm{STA}=\frac{\text { Sales }}{\text { Total Assets }}
$$

Ramadhani dan Lukviarman (2009) in Ferbianasari (2012) stated that after conducting research on selected variables and samples, Altman produced the first bankruptcy model. Bankruptcy equation aimed to predict a public manufacturing company. The equation of the first Altman model is:

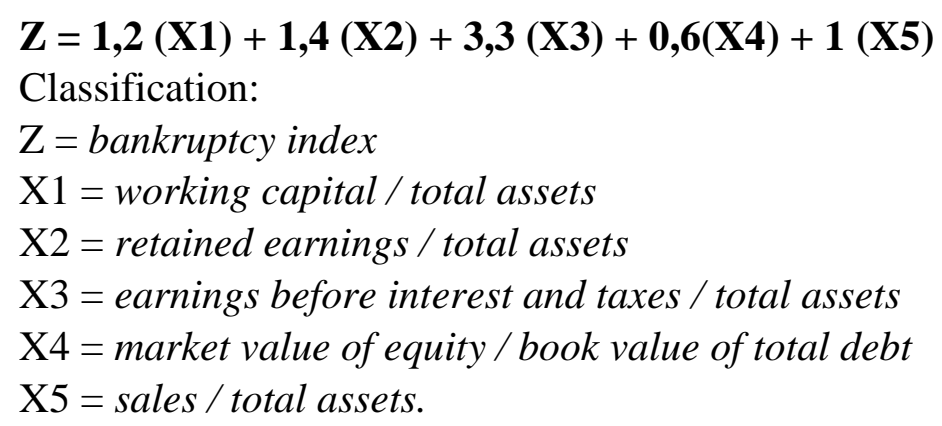

\section{Z-Score Value Interpretation Classification:}

a. Z-Score $>3.00=$ the company is considered safe/good/avoid bankruptcy risk.

b. $\quad 2.70 \leq \mathrm{Z}$-Score $<2.99=$ there is a financial condition of a company which requires special attention.

c. $\quad 1.80 \leq \mathrm{Z}$-score $<2,70=$ the company has the possibility of experiencing financial distress for the next two years.

d. Z-Score $<1,80=$ company are in high risk to experience bankrupt.

\section{FRAMEWORK}



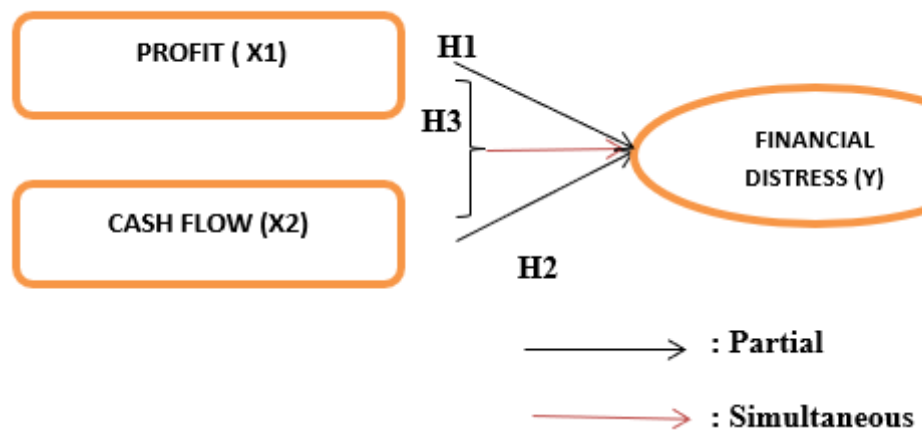

Picture 1. Framework

Source : data analysis

\section{RESEARCH METHODS}

This study uses quantitative data methods using the Altman Z-Score analysis method. Data analysis is performed through Eviews8 software application. The data used in this study are secondary data obtained from the Indonesia Stock Exchange through the website www.idx.co.id.

The population in this study are all manufacturing companies listed on the Indonesia Stock Exchange (IDX) in the period from 2015-2018. The samples used in this study are all manufacturing companies with subsector of plastic and packaging listed on the Indonesia Stock Exchange (IDX).

Purposive sampling method is used as the sampling technique, which the samples are selected based on the research objectives. The sampling criteria in this study:

a. The companies that have published audited financial statements between 2016-2018.

b. The companies that do not have a complete financial statement are excluded from the sample.

c. The companies that are not delisted during the observation period.

d. The companies that could disclose the data relating to research variables and provide the data completely.

\section{Table 1. Sample Criteria}

\begin{tabular}{ll}
\hline Company observed for samples & 14 \\
\hline $\begin{array}{l}\text { Companies that do not meet the criteria } \\
\text { are included as samples }\end{array}$ & $(4)$ \\
\hline $\begin{array}{l}\text { Selected total samples } \mathrm{x} \\
\text { period sampling }\end{array}$ & $10 \times 3=30$ \\
\hline Total samples & 30 \\
\hline
\end{tabular}

Source : the data was processed by author

\section{Data Analysis and Hypothesis Testing}

Econometric model is used to analyze the data with a simultaneous equation system and panel data estimation methods with the following equations:

$$
F D_{i t}=\beta_{0}+\beta_{1} l b_{i t}+\beta_{2} A k+\varepsilon_{i t}
$$

Which : 


$\begin{array}{ll}\mathrm{FD} & : \text { Financial Distress } \\ \mathrm{Lb} & : \text { Laba (Profit) } \\ \mathrm{Ak} & : \text { Arus Kas (Cash flow) } \\ \beta_{0} & : \text { Constant } \\ \beta_{1} \beta_{2} \beta_{3} & : \text { Regresion Coefficients } \\ \mathrm{t} & : \text { Time period (2016-2018) } \\ \mathrm{i} & : 10 \text { manufacturing companies with subsector of plastic and packaging. }\end{array}$

Tests carried out with the Classic Assumption Test and Multiple Linear Regression through Eviews-8 software application. The linear regression analysis with multiple panel data has three kinds of estimation models, namely

1. Common Effect Model (CEM)

Common effect model (CEM) is a simple model that combines all time series data with a cross section method. This model assumes that the intercepts and slopes of each variable are similiar for each object of observation, in other words, the results of this regression are considered valid for all districts/cities at all times. The weakness of this model is the incompatibility of the model with the actual situation. The condition of each object can be different and one object can have different condition from one to another time.

2. Fixed Effect Model (FEM)

Fixed effect model (FEM) is a method of estimating panel data regression models with the assumption that the coefficients of intercepts and slopes are different between cross section units but intercepts between time are constant. Generalization is often applied by inserting a dummy variable to produce slop coefficient values or parameters that vary between cross section units. This approach to inserting dummy variables is known as the fixed effect model or least square dummy variable.

3. Random Effect Model (REM)

Random effect model (REM) is used to overcome the weakness of fixed effect models that use dummy variables, so the model experiences uncertainty. The use of dummy variables will reduce the degree of freedom, which in turn will reduce the efficiency of the estimated parameters. REM uses residuals that are thought to have a relationship between time and between individuals, so REM assumes that each individual has different intercept which are included as random variables.

The decision to choose the model used in panel analysis is based on two tests, namely Chow Test and Hausman Test. The Chow Test is used to decide whether to use Common Effect or Fixed Effect. Whereas to decide whether to use the Fixed Effect or Random Effect is determined by the Hausman Test. If teoritically the impact of the disturbance cannot be determined, the Fixed Effect method is used as long as the data used includes all individuals in the population or only a few individuals but is not taken randomly. Conversely, if the data used comes from individuals taken randomly from a larger population, the Random Effect estimation method is used.

\section{FINDINGS AND DISCUSSION}


To decide which model applied in using panel data regression techniques, there are three alternative approaches to its processing, including Pooled Least Square/Common Effect Model (CEM), Fix Effect Model (FEM), and Random Effect Model (REM).

\section{Model Estimation Results}

The results of data analysis consist of two variables, namely Profit and Cash Flow. The function model used is:

$$
\text { Financial Distress } \quad=f(\text { Proft, } \text { Cash flow })
$$

Data analysis in this study uses econometrics with panel data estimation methods that refer to the research by Nailufar, F., \& Badaruddin, S. (2018). The best model which is free from multicollinearity, heterokedasticity, autocorrelation problems can be produced by using the equation function as follows:

$$
\text { Financial Distress }=3,033-3,13 \text { Profit }+2,50 \text { Cashflow }+\varepsilon_{t}
$$

Table 2. The Results of Dependent Variable Regression Against Independent

$$
\text { Variables }
$$

Dependent Variable: ZSCORE?

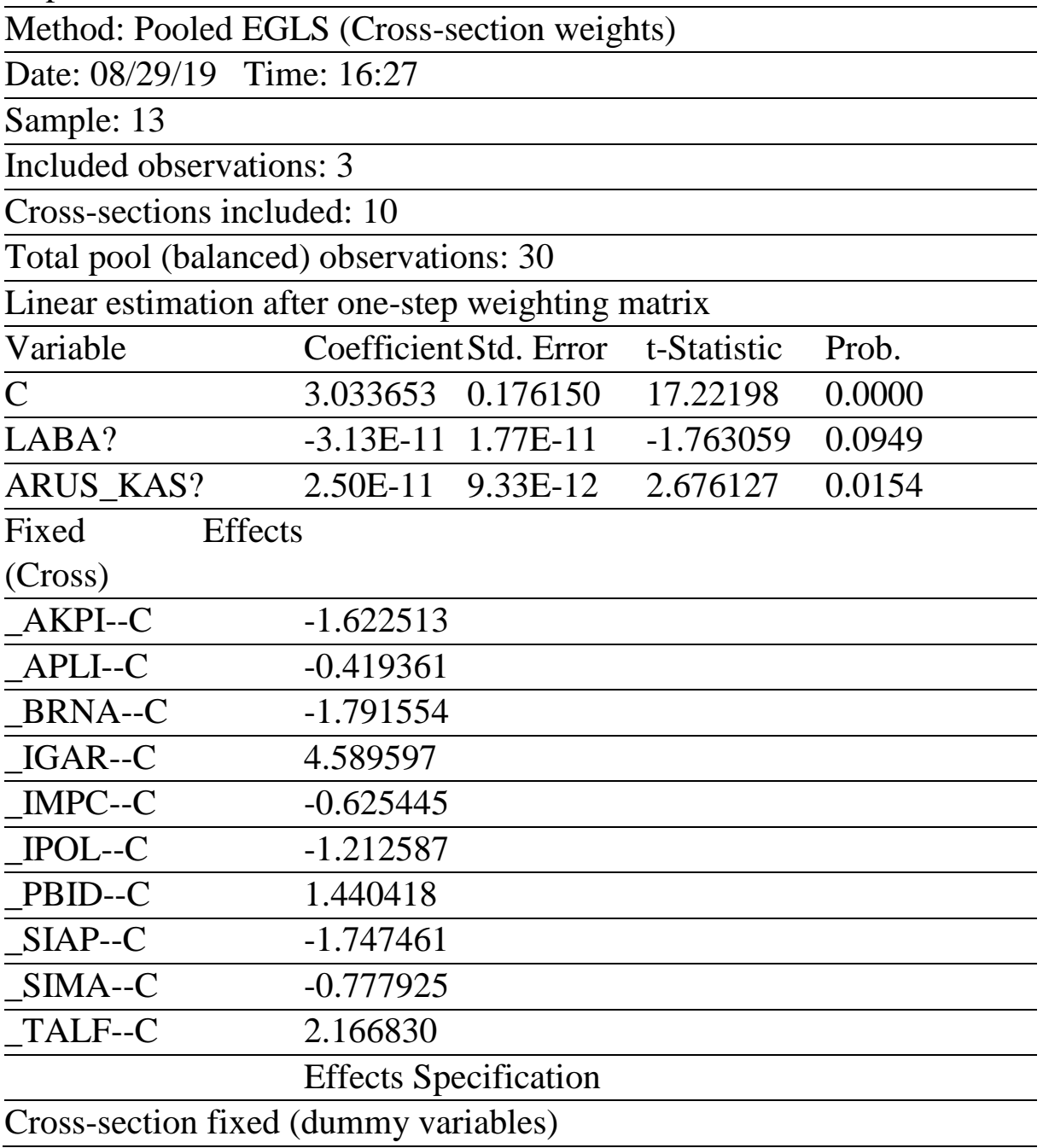




\begin{tabular}{llll}
\hline \multicolumn{4}{c}{ Weighted Statistics } \\
\hline R-squared & 0.990509 & Mean dependent var & 10.14381 \\
\hline Adjusted R-squared & 0.984709 & S.D. dependent var & 7.788217 \\
\hline S.E. of regression & 0.649223 & Sum squared resid & 7.586837 \\
\hline F-statistic & 170.7715 & Durbin-Watson stat & 3.076233 \\
\hline Prob(F-statistic) & 0.000000 & & \\
\hline \multicolumn{4}{l}{ Unweighted Statistics } \\
\hline R-squared & 0.930137 & Mean dependent var & 2.833311 \\
\hline Sum squared resid & 7.663204 & Durbin-Watson stat & 2.769042 \\
Source : Data Analysis & & &
\end{tabular}

The result of model specification test using both Chow test and Hausman test is fixed effect model, this model is considered as the proper model to analyze the effect of profit and cash flow to predict financial distress in manufacturing companies with subsector of plastic and packaging. The analysis model based on Table 4.3 explaining about the results of the profits and cash flow variables regression toward financial distress is, as follows:

Financial Distress $=3,033-3,13$ Profit $+2,50$ Cashflow $+\varepsilon_{t}$

The above equation can be interpreted as follows:

1) A constant of 3.033 states that if the independent variables, profit and cash flow, are considered constant, the magnitude of financial distress in 10 manufacturing companies with subsector of plastic and packaging is 3.033.

2) The probability value of regression coefficient of the profit variable to financial distress is -3.13 which more than $0.05(\alpha=0.05)$, it explains that there is a negative relationship between profit variable on financial distress. The value of -3.13 explains that if there is an increase in the value of profit by one percent, it will reduce the value of financial distress by -3.13 .

3) The probability value of the regression coefficient of the cash flow variable to financial distress is 2.50 which less than $(\alpha=0.05)$, it explains that there is a positive relationship between cash flow variable on financial distress. The value of 2.50 explains that if there is an increase in the value of cash flow by one percent, it will increase the value of financial distress by 2.50 .

Table 3. The constant value of $\mathbf{1 0}$ manufacturing companies with subsector of plastic and packaging

\begin{tabular}{llll}
\hline individual effect & koefisien/CI & Koefisien/C & CI+C \\
\hline _AKPI--C & $-1,622513$ & 3,033653 & 1,411140 \\
\hline _APLI--C & $-0,419361$ & 3,033653 & 2,614292 \\
\hline _BRNA--C & $-1,791554$ & 3,033653 & 1,242099 \\
\hline _IGAR--C & 4,589597 & 3,033653 & 7,623250 \\
\hline _IMPC--C & $-0,625445$ & 3,033653 & 2,408208 \\
\hline _IPOL--C & $-1,212587$ & 3,033653 & 1,821066 \\
\hline
\end{tabular}




\begin{tabular}{cccc}
\hline _PBID--C & 1,440418 & 3,033653 & 4,474071 \\
\hline -SIAP--C & $-1,747461$ & 3,033653 & 1,286192 \\
\hline -SIMA--C & $-0,777925$ & 3,033653 & 2,255728 \\
\hline -TALF--C & 2,166830 & 3,033653 & 5,200483 \\
\hline
\end{tabular}

\section{Classic Assumption Test}

\section{The Result of Normality Test}

This test will examine whether the data could be normally distributed or not which use the Jarque-Bera test (J-B test) with the following hypothesis test:

$\mathrm{H}_{0}$ : Data is not normally distributed

$\mathrm{H}_{1}$ : Data is normally distributed

The criteria of testing are:

1. If the probability value $>\alpha(0.05)$, then the data is normally distributed (Reject $\mathrm{H}_{0}$, Accept $\mathrm{H}_{1}$ ). This means that the data has passed the normality test.

2. If the probability value $<\alpha(0.05)$, then the data is not normally distributed (Accept $\mathrm{H}_{0}$, Reject $\mathrm{H}_{1}$ ). This means that the data does not pass the normality test.

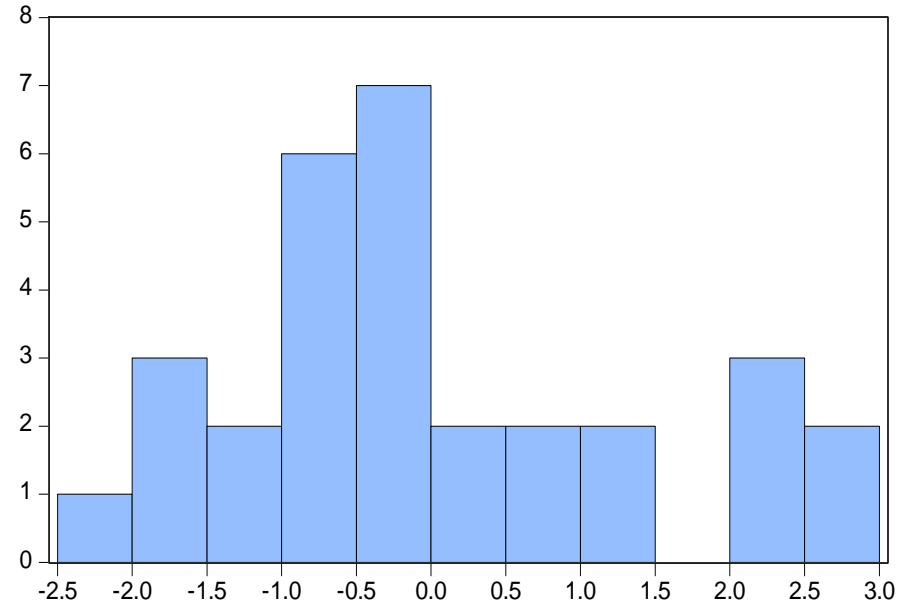

\begin{tabular}{|ll|}
\hline \multicolumn{2}{|l}{ Series: Standardized Residuals } \\
Sample 2016 2018 \\
Observations 30 \\
Mean & $-6.96 \mathrm{e}-16$ \\
Median & -0.258706 \\
Maximum & 2.819452 \\
Minimum & -2.384144 \\
Std. Dev. & 1.372847 \\
Skewness & 0.476855 \\
Kurtosis & 2.467971 \\
& \\
Jarque-Bera & 1.490773 \\
Probability & 0.474551 \\
\hline
\end{tabular}

Picture 2. Normality Testing

Source: Output Eviews 8.0 (processed)

Picture 2 explains that the data are normally distributed because the Jarque-Bera test has produced value which meets the test criteria, where if probability $>\alpha(0.05)$, then the data are normally distributed (Reject $\mathrm{H}_{0}$, Accept $\mathrm{H}_{1}$ ). It means that the data has passed the normality test. The output of the test shows that the probability value is $0.47>\alpha(0.05)$.

\section{The result of Multicollinearity Test}

This test will examine whether the data could be normally distributed or not which use the Correlation Matrix with the following hypothesis test:

$\mathrm{H}_{0}$ : multicollinearity does not occur

$\mathrm{H}_{1}$ : multicollinearity occurs

To detect the occurrence of multicollinearity in the model, several indicators are used, in the output eviews as follows: 
a. In the correlation matrix, if the correlation coefficient $<0.90$, hence there is no multicollinearity (Accept $\mathrm{H}_{0}$, Reject $\mathrm{H}_{1}$ ).

b. In the correlation matrix, if the correlation coefficient $>0.90$, hence there is multicollinearity (Reject $\mathrm{H}_{0}$, Accept $\mathrm{H}_{1}$ ).

Table 4.The Estimation Result of Multicollinearity Test

\begin{tabular}{lcc}
\hline & CASH FLOW & FROFIT \\
\hline CASH FLOW & 1.000000 & 0.875406 \\
\hline PROFIT & 0.875406 & 1.000000 \\
\hline
\end{tabular}

Source: Output eviews 8.0 (processed)

Table 4 explains that multicollinearity does not occur or there is no relationship between the independent variables because the value of correlation matrix test generated from each independent variable is $<0.90$, hence there is no multicollinearity (Accept $\mathrm{H}_{0}$, Reject $\left.\mathrm{H}_{1}\right)$.

\section{T-Statistic Test (Partial)}

This test shows to what extent the independent variables will influence individually in explaining the variation of the dependent variable. In the regression method, the influence of profit and cash flow on financial distress in 10 manufacturing companies with subsector of plastic and packaging in 2016-2018, using $\alpha=5 \%(0.05)$ and degree of freedom $(\mathrm{df}=\mathrm{nk}=30$ $-3=27$ ), made $t$-table of 2.05 .

Table 5. The result of T-Statistic Test

\begin{tabular}{ccccc}
\hline Variabel & t-count & t-table & Prob & The result of t-statistics test \\
\hline FD & 17,22 & 2,05 & 0,00 & Reject $\mathrm{H}_{0}$, Significant \\
\hline Profit & $-1,76$ & 2,05 & 0,09 & Reject $\mathrm{H}_{1}$, Not Significant \\
\hline Cash Flow & 2,67 & 2,05 & 0,01 & Reject $\mathrm{H}_{0}$, Significant \\
\hline
\end{tabular}

Source : Output Eviews 8.0 (processed)

Table 4.4, it explains that profit variable has no significant effect on financial distress, this is because t-count is smaller than $\mathrm{t}$-table, so $\mathrm{H}_{1}$ is rejected. However, cash flow variable has a positive and significant effect on financial distress, this is because the $\mathrm{t}$-count is greater than the t-table.

\section{F-Statistic Test (Simultaneous)}

The F-Statistic test is used to test the significance of the regression model, which is to reveal whether all independent variables influence the dependent variable. If the significance value is less than 0.05 (Probability $<0.05$ ), hence the regression model is statistically significant. The results of the Fixed Effect Model regression method are presented as follows. 
Table 5. The result of F-Statistic Test

\begin{tabular}{ccc}
\hline f-count & f-table & Prob (f-statistics) \\
\hline 170,77 & 19,45 & 0,00 \\
\hline
\end{tabular}

Source: Output Eviews 8.0 (processed)

It can be seen from Table 4.5 that on F-statistic test, the f-table is 17.45 and an $\mathrm{f}$-count is 170.77 , with a significance value of 0.00 at $\alpha=5$ percent. Therefore, $f$-count $>$ f-table and the significance value is less than 0.05 (Probability $<0.05$ ), hence $\mathrm{H}_{0}$ is rejected and $\mathrm{H}_{1}$ is accepted. Eventually, this study successfully proves that profit and cash flow simultaneously have a significant effect on financial distress.

\section{CONCLUSION AND SUGESTION}

Based on the results of the analysis and discussion of the study, the author conclude that profit does not have a significant effect on financial distress. This is evidenced by the results of the t-test analysis in which the t-count is smaller than t-table, indicated by the number $-1.76<2.05$. Hence, $\mathrm{H} 1$ is rejected. Cash flow has a significant effect on financial distress. This is evidenced by the results of the t-test analysis in which the t-count is greater than t-table, indicated by the number $2.67>2.05$. Hence, $\mathrm{H} 2$ is accepted. Whereas, profit and cash flow collectively have a significant influence on financial distress. This is evidenced by the results of the analysis of the F-test where f-count $>$ f-table, indicated by the figure $17.45>$ 170.77. Hence, H3 is accepted.

It is suggested that the other researchers can use other variables to measure financial distress, such as ROA variable, company performance, or company size. The use of observation year data to predict the financial distress of a company can affect the validity of the test results. Therefore, in subsequent studies it is advisable to use predictive year data over the following 2-3 years so that the results of research testing would favorably reflect the company's situation quickly. Furthermore, instead of using company annual financial statement obtained by idx.co.id, other researchers are able to search for financial report through the companies' websites or directly visit the official companies concerning for completeness of the data.

\section{REFERENCES}

Assagaf Aminullah, Murwaningsari Etty, dkk (2019). Estimates Model of Factors Affecting

Financial Distress: Evidence from Indonesian State-owned Enterprises. Asian Journal of Economics, Business and Accounting, 11(3): 1-19, 2019.

Ayoola Tajudeen John, Obokoh Lawrence Ogechukwu (2018), Corporate Governance and Financial Distress in the Banking Industry: Nigerian Experience. Journal of Economics and Behavioral Studies, Vol. 10, No. 1, pp. 182-193.

Gujarati, Damodar dan Porter, D. (2010). Dasar-Dasar Ekonometrika (edisi 5). Jakarta: Salemba Empat.

Gujarati, Damodar. 1993. Ekonometrika Dasar. cetakan ke. Jakarta: Erlangga.

Hanafi, I \& Supriyadi, S.G (2018). Prediksi Financial Distress Perusahaan Manufaktur Yang Terdaftar di BEI. Jurnal Ekuivalensi, Vol. 4 No.1, hal 24-51. 
Halim, M (2016). Penggunaan Laba dan Arus Kas Untuk Memprediksi Kondisi Financial Distress (Studi Empiris pada perusahaan manufaktur yang terdaftar di BEI).

Kieso \& Weygandt (2016) Akuntansi Intermediate, Penerbit Erlangga, Jakarta.

Katarina Intan Afni Patunrui, S. Y. (2017). Analisis Penilaian Financial Distress Menggunakan Model Altman (ZScore) Pada Perusahaan Farmasi Yang Terdaftar di Bursa Efek Indonesia. JurnalAkuntansi, Ekonomi Dan Manajemen Bisnis Vol. 5 No. 1 hal. 55-71.

Kajananthan, R (2014). Liquidity, Solvency and Profitability Analysis Using Cash Flow Ratios and Traditional Ratios: The Telecommunication Sector in Sri Lanka. Research Journal of Finance and Accounting, Vol.5, No.23, 2014.

Martani, Dwi, dkk (2016). Akuntansi Keuangan Menengah Berbasis PSAK. Penerbit Salemba Empat, Jakarta.

Mas'ud. I \& Srengga, R.M (2012). Analisis Rasio Keuangan Untuk Memprediksi Kondisi

Financial Distress Perusahaan Manufaktur yang Terdaftar di BEI. Jurnal Akuntansi Universitas Jember, hal.139-154.

Novita, S.D \&Hadi, S \&Khoirul, A (2017). Pengaruh Penggunaan Laba dan Arus Kas Terhadap Kondisi Financial Distress (Studi Pada Perusahaan PertambanganBatu Bara Yang Terdaftar di Bursa Efek Indonesia PeriodeTahun 2012-2014). E-Journal RisetManajemen FE Unisma.

Natasari, R \&Indarto, M (2014).Manfaat Laba dan Arus Kas Untuk Memprediksi Kondisi Financial Distress (Studi Pada Perusahaan Manufakturdi BEI).Jurnal Sosial Ekonomi Pembangunan Tahun IV No. 11, hal. 152-173.

Nailufar, F., \& Badaruddin, S. (2018). Pengaruh Laba dan Arus Kas Terhadap Kondisi Financial Distress Pada Perusahaan Non Bank Yang Terdaftar Di Bursa Efek Indonesia. 2(2), 147-162.

Permana, R.K \& Ahmar, N \& Djaddang, S (2017). Prediksi Financial Distress pada Perusahaan Manufaktur di BEI. Esensi: Jurnal Bisnis dan Manajemen Vol 7 (2) Oktober 2017. hal, 149-166.

Panigrahi Ashok (2019). Validity of Altman's "Z" Score Model in Predicting Financial Distress of Pharmaceutical Companies. NMIMS JOURNAL OF ECONOMICS AND PUBLIC POLICY. Vol IV Issue 1 65-73.

Ratna, I \& Marwati (2018). Analisis Faktor-faktor Yang Mempengaruhi Kondisi Financial Distress Pada Perusahaan Yang Delisting Dari Jakarta Islamic Index Tahun 2012-2016. Jurnal Tabarru: Islamic Banking and Finance, Vol.1 No. 1 Mei 2018.

Ranjbar Samin, Amanollahi Gholamreza Farsad (2018). The effect of financial distress on earnings management and unpredicted net earnings in companies listed on Tehran Stock Exchange. Management Science Letters 8 (2018) 933-938.

Rasminiati, N.K.T \& Artini, L.G.S (2018). Prediksi Kondisi Keuangan Pada Perusahaan Sektor Pertambangan di Bursa Efek Indonesia. e-Jurnal Manajemen Unud. Vol. 7 No. 11, hal. 6100-6128.

Santoso, S. I., Fala, D. Y. A. S., \& Khoirin, A. N. N. (2017). Pengaruh Laba , Arus Kas dan Corporate Governance terhadap Financial Distress. Jurnal Al-Buhuts, 1(1), 1-22. Retrieved from

Suwardjono. (2005). teori akuntansi perekayasaan pelaporan keuangan. 
Santoso, S. I., Fala, D. Y. A. S., \& Khoirin, A. N. N. (2017). Pengaruh Laba , Arus Kas dan Corporate Governance terhadap Financial Distress. Jurnal Al-Buhuts, 1(1), 1-22.

Wahyuni, ersa tri. (2012). standar akuntansi keuangan.

Zulfiqar Ali Memon and Yan Chen, Muhammad Zubair Tauni, Hashmat Ali (2018). The impact of cash flow volatility on firm leverage and debt maturity structure: evidence from China. China Finance Review International. https://doi.org/10.1108/CFRI-062017-0106

\section{Website:}

http://eprints.unm.ac.id/6646/1/PENGARUH\%20STRUKTUR\%20MODAL\%20TERHADA P\%20LABA\%20PADA\%20\%20PT.\%20TELEKOMUNIKASI\%20\%20INDONESIA $\% 20$ Tbk.pdf

http://akuntanmaniak.blogspot.com/2012/01/laba-income.html http://idx.co.id 